\title{
ВПЛИВ ІНГІБІТОРІВ АРОМАТАЗИ ТРЕТЬОГО ПОКОЛІННЯ НА ОКРЕМІ КОМПОНЕНТИ ПЕРЕБІГУ ЕКСПЕРИМЕНТАЛЬНОГО МЕТАБОЛІЧНОГО СИНДРОМУ
}

Вступ. На сьогодні серед хворих з метаболічним синдромом близько 86 \% пацієнтів мають серйозні порушення толерантності до глюкози і близько 60 \% пацієнтів страждають від вісцерального ожиріння. При цьому в багатьох світових дослідженнях показано, що ці патогенетичні прояви метаболічного синдрому в досліджуваних пацієнтів мали значну кореляцію з дисбалансом статевих гормонів.

Мета дослідження - вивчити вплив інгібіторів ароматази третього покоління на показники інсулінорезистентності й вісцерального ожиріння в хом'ячків з експериментальним метаболічним синдромом.

Методи дослідження. Рівень інсуліну в сироватці крові хом'ячків визначали імунофрерментним методом, а рівень глюкози - електрохімічним. Для оцінки вісцерального ожиріння розраховували масові коефріцієнти анатомічних фррагментів жирової тканини. Отримані результати було оброблено із застосуванням U-критерію Манна-Уітні й методу 4PI.

Результати й обговорення. Усі препарати, які вивчали, тією чи іншою мірою впливали на досліджувані патогенетичні компоненти перебігу експериментального метаболічного синдрому. Найбільшу ефрективність щодо зменшення показника інсулінорезистентності показав препарат “Екземестан", а при зменшенні ступеня вісцерального ожиріння - “Летрозол".

Висновок. Інгібітори ароматази можуть стати перспективними препаратами для впливу на патогенетичні компоненти метаболічного синдрому, зокрема на інсулінорезистентність і вісцеральне ожиріння.

КЛЮЧОВІ СЛОВА: ароматаза; інгібітори; метаболічний синдром; вісцеральний жир; інсулінорезистентність; летрозол; анастрозол; екземестан.

ВСТУП. Сучасне універсальне визначення метаболічного синдрому розглядає його як комплекс декількох патологічних станів, серед яких з особливою важливістю виділяють абдомінальне ожиріння та підвищення рівня глюкози в плазмі крові натщесерце, що з часом перетворюється на стійку інсулінорезистентність. За даними IDF (International Diabetes Federation), майже 25 \% дорослого населення світу страждають від метаболічного синдрому. Залежно від соціально-економічного статусу, генетичних особливостей, середнього віку, способу життя, схильності до куріння та інших фракторів у популяції захворюваність на метаболічний синдром у деяких регіонах світу може сягати 84 \% [1-3].

Вищезазначені компоненти метаболічного синдрому (ожиріння, гіперглікемія натще, стійка інсулінорезистентність) $€$ не тільки суто патогенетичними проявами, а й зазвичай факторами ризику розвитку хвороби з найбільшим імпактом. (с А. Л. Загайко, Д. В. Литкін, А. В. Малоштан, 2017.
Так, розповсюдженість метаболічного синдрому серед пацієнтів з ожирінням становить майже $60 \%$, а в пацієнтів з надмірною масою - $22 \%$, тоді як у людей з нормальною масою тіла метаболічний синдром трапляється лише в 5 \% випадків [1, 4].

Близько 69 \% пацієнтів з підвищеною глюкозою в плазмі крові натщесерце і 86 \% хворих на цукровий діабет страждають від метаболічного синдрому. При цьому майже у половини всіх осіб із метаболічним синдромом спостерігають збільшення базального вмісту глюкози $(47,1 \%)$, решта поділяються на осіб з нормальною толерантністю до глюкози (14,5 \%), 3 порушенням толерантності до глюкози (4,5 \%) та із цукровим діабетом (33,9 \%) [5]. Таким чином, практично в усіх пацієнтів з метаболічним синдромом відмічають надмірне значення індексу інсулінорезистентності HOMA-IR (за рахунок підвищення рівня сироваткової глюкози й інсуліну натщесерце), збільшення якого, у свою чергу, також чітко 
корелює зі зростанням індексу маси тіла й вісцеральним ожирінням [6].

Крім того, серед безпосередніх фракторів кореляції 3 наявним метаболічним синдромом відмічають стать і вік пацієнта. Світова епідеміологічна картина захворюваності на метаболічний синдром демонструє, що в різних регіонах кількість пацієнтів чоловічої статі варіює від 8 до $43 \%$, тоді як пацієнтів жіночої статі - від 7 до 56 \% [7]. Поширеність хворих з метаболічним синдромом у популяції позитивно корелює з віком пацієнтів обох статей і, починаючи з 20 років, збільшується експоненціально [4].

Кореляція ризику захворюваності на метаболічний синдром із вищезазначеними критеріями опосередковано співвідноситься зі спостереженням, що одне з центральних місць у патогенезі цього синдрому посідає дисбаланс статевих гормонів, який додатково посилюється на тлі підвищення активності ензиму жирової тканини - ароматази і залежить від віку, статі й загальної маси даної тканини. Також існує багато даних щодо безпосереднього взаємозв'язку між дисбалансом статевих гормонів і гіперглікемією та ожирінням. У роботі Qin Xu та співавт. було продемонстровано, що діабет і гіперглікемія асоційовані зі зниженням плазмового рівня тестостерону й підвищенням плазмового рівня естрадіолу [8]. Також наявні дані щодо зв'язку між збільшенням рівня естрогенів і зменшенням чутливості клітин до інсуліну. Так, високий фрізіологічний і надфрізіологічний рівень естрадіолу в пацієнтів знижує експресію інсулінозалежного транспортера глюкози GLUT4, що призводить до зростання вмісту глюкози й інсуліну в плазмі крові та, як наслідок, до збільшення індексу інсулінорезистентності HOMA-IR. Такий саме механізм лежить в основі гестаційного діабету у вагітних [9].

Дослідження впливу гормонів на ріст жирової тканини показали, що під дією естрогенів збільшується ріст жирової тканини через посилення проліфрерації преадипоцитів, що, у свою чергу, посилює периферійну ароматизацію, підвищуючи вміст естрогенів $[10,11]$. До того ж, збільшення рівня естрогенів у плазмі крові сильно корелює з ожирінням у пацієнтів чоловічої статі й помірно - у пацієнтів жіночої статі. А при вивченні окремо плазмового рівня естрону (головного продукту ароматазної реакції) було виявлено високу кореляцію з ожирінням і в жінок [12-14].

Враховуючи вищезазначене, можна висунути гіпотезу стосовно ймовірності впливати на основні прояви метаболічного синдрому (абдомінально-вісцеральне ожиріння, підвищення рівня глюкози натщесерце та стійку інсулінорезистентність) через корекцію гормонального статусу пацієнта, а саме через зменшення ароматазної активності жирової тканини.

Препарати з групи інгібіторів ароматази третього покоління, такі, як летрозол, анастрозол і екземестан, здатні ефективно інгібувати цю ферментативну реакцію не тільки в органах статевої системи, а й у периферійних тканинах.

Мета дослідження - вивчити вплив інгібіторів ароматази третього покоління на показники інсулінорезистентності й вісцерального ожиріння в хом'ячків з експериментальним метаболічним синдромом.

МЕТОДИ ДОСЛІДЖЕННЯ. Дослідження проводили на 200 сирійських хом'ячках (Mesocricetusauratus) обох статей віком 1 і 2,5 місяця на початок експерименту. Відповідно до статі й віку, тварин (самці, самиці/молоді, зрілі) порівну поділили на 4 експериментальних кластери, кожен з яких поділили на 5 експериментальних підгруп по 10 хом'ячків у кожній:

- підгрупа тварин інтактного контролю (IK);

- підгрупа тварин контрольної патології (КП);

- підгрупа тварин, які отримували екземестан (Ек);

- підгрупа тварин, які отримували летрозол (Лт);

- підгрупа тварин, які отримували анастрозол (Ан).

Експериментальну патологію (аліментарний метаболічний синдром) моделювали відповідно до методичних рекомендацій із використанням висококалорійної дієти з великим вмістом жирів і вуглеводів (високою часткою фруктози) впродовж 6-ти тижнів $[15,16]$. Тварин, які входили до підгрупи інтактного контролю, утримували на збалансованому стандартному раціоні для хом'ячків упродовж всього експерименту.

На перебіг експериментального метаболічного синдрому впливали через зменшення периферійної ароматазної активності жирової тканини тварин препаратом з класу стероїдних інгібіторів ароматази - екземестаном (Екземестан-ВICTA $®$, табл. 25 мг, № 30, № UA/14554/01/01) і препаратами 3 класу триазольних інгібіторів ароматази - летрозолом (Летромара $®$, табл. 2,5 мг, № 30, № UA/4698/01/01) й анастрозолом (Анастрозол САНДОЗ®, табл. 1 мг, № 28, № UA/13575/01/01). Дози препаратів, еквівалентні для тварин, було розраховано на основі середньотерапевтичних добових доз препаратів для людини, міжвидової різниці маси та площі поверхні тіла і встановлено в кількості 3,086 мг/кг екземестану, 0,309 мг/кг летрозолу й 0,126 мг/кг анастрозолу на добу для хом'ячків [17].

Інгібітори ароматази починали вводити після відтворення експериментальної моделі (через 
6 тижнів після початку експерименту). Необхідну індивідуальну для тварини дозу препарату зважували, після чого диспергували в одному мілілітрі води очищеної та вводили один раз на добу внутрішньошлунково за допомогою спеціального зонда впродовж 3-х тижнів. Тварини, які не отримували препаратів, замість них одержували лише воду очищену в тому ж об'ємі для відтворення рівних умов експерименту. Після початку лікування раціон тварин усіх експериментальних груп залишався незмінним. Таким чином, режим введення препаратів дає змогу оцінити вплив тільки медикаментозного лікування на перебіг експериментального метаболічного синдрому й екстраполювати отримані результати на пацієнтів, у яких дієта не показує ефрективних результатів через низьку комплаєнтність та інші срактори.

Після курсового введення препаратів упродовж 21-ї доби (або еквівалентного часу очікування в разі позитивного і негативного контролю) тварин виводили з експерименту та відбирали біологічний матеріал. Заздалегідь їх було позбавлено вільного доступу до їжі. У тварин збирали кров для отримання сироватки і хірургічно вилучали ретроперитонеальну та мезентеральну вісцеральну жирову тканину [18].

Масу вилученої вісцеральної жирової тканини (ретроперитонеальної та мезентеральної жирової тканини окремо) визначали шляхом зважування одразу після вилучення на лабораторних електронних вагах EJ-6100 (“AnD", Японія). Масові коефріцієнти (МК) ії сегментів обчислювали в перерахунку на 100 г маси тіла тварини.

Рівень глюкози в сироватці крові визначали електрохімічним експрес-методом за допомогою глюкометра OneTouchUltraEasy ${ }^{\circledR}$ ("LifeScan", США) із застосуванням тест-смужок OneTouchUltra $^{\circledR}$ (“LifeScan”, США) згідно 3 інструкцією до застосування.

Рівень інсуліну в сироватці крові визначали імуносрерментним методом ELISA за допомогою стандартного набору реактивів ("DRG Instruments", Німеччина) на імуноферментному аналізаторі StatFax 303 plus ("AwarenessTechnology", США) [19].

Отримані результати статистично обробляли 3 використанням непараметричних методів аналізу (Mann-Whitney U-Test) за допомогою комп'ютерних програм STATISTICA 7.0 та MS Excel 2007 $[20,21]$. Індекс інсулінорезистентності розраховували за алгоритмом НОМА із застосуванням HOMA-IR калькулятора, розробленого Оксфрордським центром діабету, ендокринології та метаболізму $[22,23]$. Результати імуноорерментного аналізу було оброблено статистико-логістичним методом 4PI за допомогою інтернет-сервісу для вільного використання MyAssays ${ }^{\circledR}$.

РЕЗУЛЬТАТИ Й ОБГОВОРЕННЯ. ЗДаТНістЬ досліджуваних препаратів впливати на перебіг аліментарно викликаного метаболічного синдрому оцінювали в рамках еквівалента лікувального режиму після повного відтворення модельної патології і тритижневого періоду введення інгібіторів ароматази, впродовж якого раціон хом'ячків залишався незмінним. У тварин підгруп IK і КП, для відтворення рівних умов експерименту, замість періоду лікування був період очікування з відповідним незмінним раціоном харчування. На тлі експериментального метаболічного синдрому в усіх нелікованих хом'ячків спостерігали зміни показників інсулінорезистентності в сироватці крові й масових часток вісцеральної жирової тканини, що вірогідно відрізнялися від інтактних значень. Середні значення всіх показників тварин підгрупи IК перебували в межах фрізіологічної та вікової норми [24].

У самців віком 1 місяць (на початок експерименту) під впливом дієти з високим вмістом жирів і вуглеводів (переважно фрруктози) підвищувався рівень циркулюючої глюкози й імунореактивного інсуліну в сироватці крові - майже в 2,4 та 1,9 раза відповідно, що, у свою чергу, призвело до збільшення показника інсулінорезистентності на 156,5 \% порівняно з інтактом (табл. 1).

Після лікування тварин екземестаном у добовій дозі 3,086 мг/кг впродовж 3-х тижнів у сироватці крові молодих хом'ячків-самців відмічали майже повну нормалізацію досліджуваних показників інсулінорезистентності, значення яких вірогідно не відрізнялися від показників підгрупи IK ( $p>0,05)$, а середнє значення HOMA-IR у підгрупі дорівнювало приблизно 2,6, що в 2,1 раза було меншим за патологічне (табл. 1).

Інгібітор ароматази летрозол у дозі 0,309 мг/кг вірогідно впливав на прояви інсулінорезистентності в хом'ячків-самців молодого віку, але не призводив до повної нормалізації досліджуваних показників. Препарат вірогідно впливав на зменшення вмісту глюкози в крові майже на 43 \% і знижував вміст імунореактивного інсуліну практично до інтактних значень $(p>0,05)$. Але індекс інсулінорезистентності у тварин цієї підгрупи все ж таки відрізнявся від аналогічного показника в підгрупі здорових тварин, хоча й був майже вполовину менший, ніж у підгрупі КП $(p \leq 0,05)$ (табл. 1).

Під впливом анастрозолу не відзначали статистично значущого зниження рівня циркулюючої глюкози, але було помічено вірогідне зменшення сироваткового інсуліну на 20,6 \% порів- 
няно з рівнем цього гормону у тварин підгрупи КП, що математично відображалося в зменшенні показника індексу інсулінорезистентності на 25,3 \% відносно нелікованих хом'ячків $(p \leq 0,05)$ (табл. 1).

3 результатів, наведених у таблиці 2, видно, що під впливом розвинення модельної патології у зрілих хом'ячків-самців практично в 1,9 раза збільшувався і рівень сироваткової глюкози, і рівень імунореактивного інсуліну, а значення HOMA-IR зростало на 123,8 \%.

Курс лікування тварин екземестаном істотно зменшував рівень глюкози в сироватці крові (навіть порівняно з інтактом), сприяв нормалізації рівня інсуліну й, у результаті, приводив до повернення значення індексу інсулінорезистентності в межі норми (табл. 2).

Після тривалого лікування зрілих хом'ячків-самців летрозолом у дозі 0,309 мг/кг всі досліджувані показники інсулінорезистентності також вірогідно не відрізнялися від аналогічних значень у підгрупі ІК, що свідчить про нормалізацію вуглеводного обміну в цих тварин (табл. 2).

У зрілих самців, які отримували анастразол у дозі 0,126 мг/кг впродовж 3-х тижнів, не відмічали статистично значущих змін досліджуваних показників, що свідчить про незначну ефективність цього препарату в даній дозі й у даному лікувальному режимі щодо зрілих хом'ячків-самців з метаболічним синдромом. Але, все ж таки, слід відзначити тенденцію до зниження показника HOMA-IR (як й індексоутворювальних показників) на 22,9 \% порівняно 3 підгрупою КП ( $>>0,05)$ (табл. 2).

У хом'ячків-самиць молодого віку з експериментальним метаболічним синдромом на тлі висококалорійного раціону харчування збільшувався вміст глюкози й інсуліну в сироватці крові (майже однаково - у 2,1 раза), через що НОМАIR зростав на 153,2 \% (табл. 3).

У самиць, які на початок експерименту були віком 1 місяць, внутрішньошлункове введення екземестану в дозі 3,086 мг/кг протягом 21-ї доби сприяло вірогідному зменшенню сироваткової глюкози на 15,9 \%, імунореактивного інсуліну на 25,2 \%, показника HOMA-IR - на 28,2 \% порівняно 3 відповідними значеннями у тварин підгрупи КП (табл. 3).

У підгрупі хом'ячків, які отримували летразол у дозі 0,309 мг/кг, було помічено зниження рівня глюкози натщесерце на 26,2 \% порівняно 3 нелікованими тваринами, а рівень інсуліну в са-

Таблиця 1 - Показники інсулінорезистентності в сироватці крові сирійських хом'ячків-самців молодого віку за експериментального метаболічного синдрому $\left(\bar{X} \pm S_{X}, n=10\right)$

\begin{tabular}{|c|c|c|c|}
\hline $\begin{array}{c}\text { Експериментальна } \\
\text { підгрупа }\end{array}$ & Глюкоза, ммоль/л & Інсулін, пмоль/л & HOMA-IR \\
\hline IK & $5,30 \pm 0,29$ & $99,45 \pm 7,99$ & $2,14 \pm 0,19$ \\
\hline КП & $12,81 \pm 0,74^{*}$ & $186,07 \pm 13,62^{\star}$ & $5,49 \pm 0,53^{\star}$ \\
\hline Ек & $6,24 \pm 0,42^{\star \star}$ & $113,05 \pm 10,12^{\star \star}$ & $2,56 \pm 0,27^{\star \star}$ \\
\hline Лт & $7,30 \pm 0,43^{\star / \star \star}$ & $120,96 \pm 10,54^{\star \star}$ & $2,85 \pm 0,26^{\star / \star \star}$ \\
\hline Ан & $11,21 \pm 0,72^{\star}$ & $147,76 \pm 15,10^{\star / \star \star}$ & $4,10 \pm 0,50^{\star / \star \star}$ \\
\hline
\end{tabular}

Примітки. Тут і в таблицях 2-8:

1. * - відмінності вірогідні відносно тварин підгрупи інтактного контролю $(p \leq 0,05)$.

2. ** - відмінності вірогідні відносно тварин підгрупи контрольної патології $(p \leq 0,05)$.

Таблиця 2 - Показники інсулінорезистентності в сироватці крові сирійських хом'ячків-самців зрілого віку за експериментального метаболічного синдрому $\left(\overline{\mathrm{X}} \pm \mathrm{S}_{\mathrm{x}}, \mathrm{n}=10\right)$

\begin{tabular}{|c|c|c|c|c|}
\hline \multirow{6}{*}{ 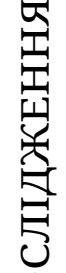 } & $\begin{array}{c}\text { Експериментальна } \\
\text { підгрупа }\end{array}$ & Глюкоза, ммоль/л & Інсулін, пмоль/л & HOMA-IR \\
\hline & IK & $5,10 \pm 0,22$ & $88,27 \pm 7,94$ & $1,89 \pm 0,19$ \\
\hline & КП & $9,46 \pm 0,33^{*}$ & $168,15 \pm 14,35^{\star}$ & $4,23 \pm 0,37^{*}$ \\
\hline & EK & $3,52 \pm 0,22^{\star / \star \star}$ & $110,85 \pm 13,84^{\star \star}$ & $2,08 \pm 0,29^{\star \star}$ \\
\hline & Лт & $4,65 \pm 0,30$ ** & $93,05 \pm 9,68^{\star \star}$ & $1,93 \pm 0,23^{\star \star}$ \\
\hline & $\mathrm{AH}$ & $7,91 \pm 0,63^{*}$ & $134,51 \pm 12,72^{*}$ & $3,26 \pm 0,36^{*}$ \\
\hline
\end{tabular}

Таблиця 3 - Показники інсулінорезистентності в сироватці крові сирійських хом'ячків-самиць молодого віку за експериментального метаболічного синдрому $\left(\bar{X} \pm S_{X}, n=10\right)$

\begin{tabular}{|c|c|c|c||}
\hline $\begin{array}{c}\text { Експериментальна } \\
\text { підгрупа }\end{array}$ & Глюкоза, ммоль/л & Інсулін, пмоль/л & HOMA-IR \\
\hline IК & $5,09 \pm 0,37$ & $86,35 \pm 9,68$ & $1,86 \pm 0,24$ \\
\hline КП & $10,46 \pm 0,56^{\star}$ & $179,69 \pm 12,39^{\star}$ & $4,71 \pm 0,38^{\star}$ \\
\hline Ек & $8,80 \pm 0,62^{\star / \star \star}$ & $134,49 \pm 12,78^{\star / \star \star}$ & $3,38 \pm 0,38^{\star / \star \star}$ \\
\hline Лт & $7,72 \pm 0,59^{\star / \star \star}$ & $117,79 \pm 11,68^{\star \star}$ & $2,86 \pm 0,34^{\star / \star \star}$ \\
\hline Ан & $9,83 \pm 0,44^{\star}$ & $153,02 \pm 12,57^{\star}$ & $3,95 \pm 0,36^{\star}$ \\
\hline
\end{tabular}


миць цієї підгрупи вірогідно не відрізнявся від показника інтактного контролю. Такий вплив на вищезазначені показники сприяв зменшенню індексу інсулінорезистентності на 39,3 \% від патологічного контролю (табл. 3).

У самиць, яким вводили анастрозол у дозі 0,126 мг/кг, значення всіх досліджуваних показників вірогідно не відрізнялися від відповідних значень підгрупи КП, хоча й були трохи меншими. Індекс інсулінорезистентності у тварин цієї підгрупи мав тенденцію до зниження на 16,1 \% порівняно 3 відповідним показником у підгрупі КП (р>0,05) (табл. 3).

У сироватці крові зрілих самиць з підгрупи КП на тлі експериментального метаболічного синдрому відмічали підвищення рівня циркулюючої глюкози й імунореактивного інсуліну в 2,1 раза, через що показник HOMA-IR зріс на 161,5 \% порівняно 3 інтактом (табл. 4).

За допомогою внутрішньошлункового введення екземестану протягом 3-х тижнів вдалося нормалізувати всі досліджувані показники інсулінорезистентності, які не мали статистично значущих відмінностей від відповідних аналогічних показників підгрупи ІК (табл. 4).

При застосуванні триазидних інгібіторів ароматази - летрозолу й анастрозолу в зрілих самиць відмічали часткову нормалізацію окремих показників вуглеводного обміну, що робило значення HOMA-IR у цих двох підгрупах майже однаковим і вірогідно нижчим (на 45,9 та 44,8 \% відповідно) за цей показник у підгрупі КП (табл. 4).

Результати, отримані при дослідженні показників вуглеводного обміну й інсулінорезистентності в хом'ячків з метаболічним синдромом на тлі тритижневого внутрішньошлункового введення інгібіторів ароматази третього покоління, демонструють, що:
- екземестан у дозі 3,086 мг/кг практично приводив досліджувані показники до інтактних значень у самців різного віку й у зрілих самиць та ефективно їх зменшував у молодих самиць;

- летрозол у дозі 0,309 мг/кг був здатний нормалізувати досліджувані показники в крові самців зрілого віку й ефективно зменшувати показник HOMA-IR (за рахунок глюкози та/або інсуліну) в усіх інших підгрупах;

- анастрозол у дозі 0,126 мг/кг ефрективно зменшував показник HOMA-IR у самців молодого віку й у самиць зрілого віку, але в інших підгрупах індекс інсулінорезистентності вірогідно не відрізнявся від значення контрольної патології, хоча й мав тенденцію до зниження.

При дослідженні МК сегментів вісцеральної жирової тканини в хом'ячків-самців молодого віку з експериментальним метаболічним синдромом, які належали до підгрупи КП, видно, що під впливом довгострокової висококалорійної дієти маса ретроперитонеальної і мезентеральної жирової тканини щодо відносної маси тіла вірогідно збільшувалася на 111,2 та 114,8 \% відповідно порівняно з інтактними показниками. При лікуванні тварин цієї підгрупи інгібіторами ароматази впродовж 21-ї доби екземестан сприяв статистично значущому зниженню середнього показника МК ретроперитонеальної і мезентеральної жирової тканини на 38,1 та 31,9 \% відповідно, летрозол - на 27,7 і 13,8 \% відповідно від значень масових коефіцієнтів жирової тканини хом'ячків з підгрупи КП. Після отримання анастрозолу в дозі 0,126 мг/кг у молодих хом'ячків-самців значення відносної маси ретроперитонеальної жирової тканини вірогідно не відрізнялося від інтактного показника, а середній МК мезентерального жиру був на 24,3 \% меншим, ніж у нелікованих тварин (табл. 5).

Таблиця 4 - Показники інсулінорезистентності в сироватці крові сирійських хом'ячків-самиць зрілого віку за експериментального метаболічного синдрому $\left(\bar{X} \pm S_{x}, n=10\right)$

\begin{tabular}{|c|c|c|c|}
\hline $\begin{array}{c}\text { Експериментальна } \\
\text { підгрупа }\end{array}$ & Глюкоза, ммоль/л & Інсулін, пмоль/л & HOMA-IR \\
\hline $\mathrm{IK}$ & $5,44 \pm 0,36$ & $95,04 \pm 8,37$ & $2,05 \pm 0,18$ \\
\hline $\mathrm{KП}$ & $11,37 \pm 0,69^{\star}$ & $197,24 \pm 16,83^{\star}$ & $5,36 \pm 0,54^{\star}$ \\
\hline Ек & $5,66 \pm 0,51^{\star \star}$ & $115,35 \pm 11,76^{\star \star}$ & $2,54 \pm 0,31^{\star \star}$ \\
\hline Лт & $7,69 \pm 0,62^{\star / \star \star}$ & $120,18 \pm 9,62^{\star \star}$ & $2,90 \pm 0,29^{\star / \star \star}$ \\
\hline Ан & $6,11 \pm 0,50^{\star \star}$ & $132,20 \pm 14,18^{\star / \star \star}$ & $2,96 \pm 0,37^{\star / \star \star}$ \\
\hline
\end{tabular}

Таблиця 5 - Масові коефіцієнти сегментів вісцеральної жирової тканини сирійських хом'ячків-самців молодого віку за експериментального метаболічного синдрому $\left(\overline{\mathrm{X}} \pm \mathrm{S}_{\mathrm{x}}, \mathrm{n}=10\right)$

\begin{tabular}{|c|c|c|}
\hline $\begin{array}{c}\text { Експериментальна } \\
\text { підгрупа }\end{array}$ & $\begin{array}{c}\text { Ретроперитонеальна жирова тканина, } \\
\text { г/100 г }\end{array}$ & $\begin{array}{c}\text { Мезентеральна жирова } \\
\text { тканина, г/100 г }\end{array}$ \\
\hline $\mathrm{IK}$ & $0,767 \pm 0,042$ & $1,121 \pm 0,039$ \\
\hline $\mathrm{K}$ & $1,620 \pm 0,049^{\star}$ & $2,408 \pm 0,033^{\star}$ \\
\hline $\mathrm{EK}$ & $1,002 \pm 0,024^{\star / \star \star}$ & $1,639 \pm 0,059^{* / \star \star}$ \\
\hline Лт & $1,172 \pm 0,025^{\star / \star \star}$ & $2,076 \pm 0,043^{\star / \star \star}$ \\
\hline $\mathrm{AH}$ & $0,866 \pm 0,054^{\star \star}$ & $1,824 \pm 0,028^{* / \star \star}$ \\
\hline
\end{tabular}


У самців, які на початок експерименту були віком 2,5 місяця, на тлі аліментарного метаболічного синдрому масовий коефіцієнт ретроперитонеальної жирової тканини був більшим на $60,3 \%$, а мезентеральної - на 149,7 \%, ніж у здорових тварин. При цьому у тварин усіх підгруп, які отримували препарати, відмічали вірогідне зменшення МК вісцеральної ретроперитонеальної і мезентеральної жирової тканини порівняно з показниками підгрупи КП: у підгрупі Ек - на 23 і 34,5 \% відповідно, в підгрупі Лт - на 17,2 і 21,2 \% відповідно та в підгрупі Ан - на 12,5 і 20,4 \% відповідно (табл. 6).

У молодих самиць з підгрупи КП під впливом висококалорійної дієти спостерігали значуще збільшення ретроперитонеального сегмента вісцеральної жирової тканини на 150,1%, мезентерального - на 113,8 \% порівняно 3 аналогічними показниками у здорових тварин. Під впливом екземестану в дозі 3,086 мг/кг середній показник МК ретроперитонеальної жирової тканини в цій підгрупі був нижчим на 39,7 \%, ніж у хом'ячків з підгрупи КП, але значення МК мезентерального жиру не мало вірогідних відмінностей, хоча й було трохи меншим. Добрий результат у даній підгрупі продемонстрував летразол, який при курсовому введенні приводив до вірогідного зменшення ретроперитонеальної жирової тканини на 46,7 \%, а мезентеральної - на
30,3 \%. Після лікування молодих хом'ячків-самиць анастрозолом у дозі 0,126 мг/кг відмічали значне зниження МК ретроперитонеальної жирової тканини майже до інтактних показників ( $>0,05)$ і значне зменшення мезентеральної жирової тканини на 34,9 \% порівняно 3 аналогічним результатом у підгрупі КП (табл. 7).

Під впливом раціону харчування, багатого на жири і вуглеводи, у зрілих самиць при відсутності лікування відмічали значуще збільшення МК сегментів вісцеральної жирової тканини - на 160,9 \% (ретроперитонеальної) та 69,9 \% (мезентеральної). Застосування екземестану в цій підгрупі приводило до вірогідного зниження масового коефіцієнта ретроперитонеального жиру на 21,2 \% і практично зменшувало МК мезентеральної жирової тканини до рівня інтактних показників ( $>>0,05)$. Курсове лікування тварин летрозолом було дуже ефективним у цій підгрупі: викликало зменшення відносної маси ретроперитонеальної жирової тканини на 42,5 \% і повністю нівелювало негативний вплив дієти на ріст мезентеральної жирової тканини ( $p>0,05$ відносно тварин підгрупи ІК). У зрілих хом'ячків-самиць анастразол продемонстрував помірний результат із вірогідним зменшенням МК ретроперитонеальної жирової тканини на 21,6 \% і мезентеральної - на 12,1% порівняно з аналогічними показниками в підгрупі КП (табл. 8).

Таблиця 6 - Масові коефіцієнти сегментів вісцеральної жирової тканини сирійських хом'ячків-самців зрілого віку за експериментального метаболічного синдрому $\left(\bar{X} \pm S_{x}, n=10\right)$

\begin{tabular}{|c|c|c||}
\hline $\begin{array}{c}\text { Експериментальна } \\
\text { підгрупа }\end{array}$ & $\begin{array}{c}\text { Ретроперитонеальна жирова } \\
\text { тканина, г/100 г }\end{array}$ & $\begin{array}{c}\text { Мезентеральна жирова } \\
\text { тканина, г/100 г }\end{array}$ \\
\hline IК & $0,771 \pm 0,042$ & $0,895 \pm 0,036$ \\
\hline КП & $1,236 \pm 0,048^{\star}$ & $2,235 \pm 0,079^{\star}$ \\
\hline Ек & $0,952 \pm 0,032^{\star / \star \star}$ & $1,463 \pm 0,035^{\star / \star \star}$ \\
\hline Лт & $1,023 \pm 0,080^{\star / / \star}$ & $1,761 \pm 0,157^{\star / \star \star}$ \\
\hline Ан & $1,081 \pm 0,044^{\star / \star \star}$ & $1,778 \pm 0,029^{\star / \star \star}$ \\
\hline
\end{tabular}

Таблиця 7 - Масові коефіцієнти сегментів вісцеральної жирової тканини сирійських хом'ячків-самиць молодого віку за експериментального метаболічного синдрому $\left(\bar{X} \pm S_{x}, n=10\right)$

\begin{tabular}{|c|c|c|}
\hline $\begin{array}{c}\text { Експериментальна } \\
\text { підгрупа }\end{array}$ & $\begin{array}{c}\text { Ретроперитонеальна жирова } \\
\text { тканина, г/100 г }\end{array}$ & $\begin{array}{c}\text { Мезентеральна жирова тканина, } \\
\text { г/100 г }\end{array}$ \\
\hline IК & $1,114 \pm 0,050$ & $1,175 \pm 0,052$ \\
\hline КП & $2,786 \pm 0,118^{\star}$ & $2,512 \pm 0,142^{\star}$ \\
\hline Ек & $1,679 \pm 0,102^{\star / * \star}$ & $2,203 \pm 0,075^{\star}$ \\
\hline Лт & $1,484 \pm 0,135^{\star / \star \star}$ & $1,752 \pm 0,103^{\star / / \star}$ \\
\hline Ан & $1,232 \pm 0,057^{\star \star}$ & $1,636 \pm 0,128^{\star / \star \star}$ \\
\hline
\end{tabular}

Таблиця 8 - Масові коесіцієнти сегментів вісцеральної жирової тканини сирійських хом'ячків-самиць зрілого віку за експериментального метаболічного синдрому $\left(\overline{\mathrm{X}} \pm \mathrm{S}_{\mathrm{x}}, \mathrm{n}=10 \overline{\mathrm{X}}\right)$

\begin{tabular}{|c|c|c|}
\hline $\begin{array}{c}\text { Експериментальна } \\
\text { підгрупа }\end{array}$ & $\begin{array}{c}\text { Ретроперитонеальна жирова } \\
\text { тканина, г/100 г }\end{array}$ & $\begin{array}{c}\text { Мезентеральна жирова } \\
\text { тканина, г/100 г }\end{array}$ \\
\hline $\mathrm{IK}$ & $0,927 \pm 0,038$ & $1,119 \pm 0,042$ \\
\hline $\mathrm{K}$ & $2,419 \pm 0,033^{\star}$ & $1,901 \pm 0,039^{\star}$ \\
\hline $\mathrm{EK}$ & $1,906 \pm 0,043^{\star / \star \star}$ & $1,208 \pm 0,045^{\star \star}$ \\
\hline Лт & $1,392 \pm 0,054^{\star / \star \star}$ & $1,023 \pm 0,056^{\star \star}$ \\
\hline $\mathrm{AH}$ & $1,896 \pm 0,170^{\star / \star \star}$ & $1,671 \pm 0,074^{\star / \star \star}$ \\
\hline
\end{tabular}


Результати, отримані при дослідженні масових коефріцієнтів окремих сегментів вісцеральної жирової тканини в хом'ячків з метаболічним синдромом на тлі тритижневого внутрішньошлункового введення інгібіторів ароматази третього покоління, демонструють, що:

- екземестан у дозі 3,086 мг/кг був здатний есрективно пригнічувати патологічне збільшення окремих сегментів вісцеральної жирової тканини майже в усіх підгрупах, а в зрілих самиць майже повністю пригнічував ріст мезентерального жиру, але в самиць молодого віку щодо мезентеральної жирової тканини ефект був мінімальним;

- летрозол у дозі 0,309 мг/кг мав стабільну високу есективність із пригнічення росту вісцеральної жирової тканини в усіх без винятку підгрупах, а в зрілих самиць навіть повністю нівелював негативний вплив висококалорійної дієти на ріст мезентеральної жирової тканини;

- анастрозол у дозі 0,126 мг/кг помірно й ефективно зменшував ріст вісцеральної жирової тканини, а в молодих тварин обох статей знижував МК ретроперитонеальної жирової тканини до інтактного рівня.

ВИСНОВКИ. Під впливом тритижневого внутрішньошлункового введення досліджуваних інгібіторів ароматази третього покоління в еквівалентних для тварин дозах у хом'ячків різної статі й віку з експериментально індукованим аліментарним метаболічним синдромом відбувалися зміни індексу інсулінорезистентності й масових коесріцієнтів окремих сегментів вісцеральної жирової тканини:

1. Під впливом екземестану в дозі 3,086 мг/кг: у молодих самців середнє значення HOMA-IR зменшувалося майже до рівня здорових тварин ( $>>0,05)$, а масові коесріцієнти окремих сегментів вісцеральної жирової тканини знижувалися на 38,1 і 31,9 \%; у зрілих самців середнє значення HOMA-IR зменшувалося майже до рівня здорових тварин ( $>>0,05)$, а масові коефіцієнти окремих сегментів вісцеральної жирової тканини знижувалися на 23 та $34,5 \%$; у молодих самиць середнє значення HOMA-IR зменшувалося на $28,2 \%$, масовий коефіцієнт ретроперитонеаль-

\section{СПИСОК ЛІТЕРАТУРИ}

1. Kaur J. Comprehensive review on metabolic syndrome [Published online] / J. Kaur // Cardiology Research and Practice, Article ID 943162. - 2014. - Access mode: https://www.hindawi.com/journals/crp/2014/943162/. ної жирової тканини знижувався на $39,7 \%$, тоді як масовий коефріцієнт мезентеральної жирової тканини майже не змінювався; у зрілих самиць середнє значення HOMA-IR зменшувалося майже до рівня здорових тварин ( $>>0,05)$, масовий коефріцієнт ретроперитонеальної жирової тканини знижувався на 21,2 \%, а мезентеральної майже до рівня здорових тварин ( $>>0,05)$.

2. Під впливом летрозолу в дозі 0,309 мг/кг: у молодих самців середнє значення HOMA-IR зменшувалося майже в 2 рази, а масові коефріцієнти окремих сегментів вісцеральної жирової тканини знижувалися на 27,7 і 13,8 \%; у зрілих самців середнє значення HOMA-IR зменшувалося майже до рівня здорових тварин $(p>0,05)$, а масові коесріцієнти окремих сегментів вісцеральної жирової тканини знижувалися на 17,2 та 21,2 \%; у молодих самиць середнє значення HOMA-IR зменшувалося на 39,3 \%, масові коефіцієнти окремих сегментів вісцеральної жирової тканини знижувалися на 46,7 і 30,3 \%; у зрілих самиць середнє значення HOMA-IR зменшувалося на 45,9\%, масовий коесріцієнт ретроперитонеальної жирової тканини знижувався на 42,5 \%, а мезентеральної - майже до рівня здорових тварин ( $>>0,05)$.

3. Під впливом анастрозолу в дозі 0,126 мг/кг: у молодих самців середнє значення HOMA-IR зменшувалося на 25,3 \%, масовий коефріцієнт ретроперитонеальної жирової тканини знижувався майже до рівня здорових тварин $(p>0,05)$, а мезентеральної - на 24,3 \%; у зрілих самців середнє значення HOMA-IR зменшувалося на 22,9 \% (не вірогідно), а масові коефріцієнти окремих сегментів вісцеральної жирової тканини знижувалися на 12,5 і 20,4 \%; у молодих самиць середнє значення HOMA-IR зменшувалося на 16,1 \% (не вірогідно), масовий коесріцієнт ретроперитонеальної жирової тканини знижувався майже до рівня здорових тварин ( $>>0,05)$, а мезентеральної - на 34,9\%; у зрілих самиць середнє значення HOMA-IR зменшувалося на 44,8 \%, масовий коесріцієнт ретроперитонеальної жирової тканини зменшувався на $42,5 \%$, а масові коефріцієнти окремих сегментів вісцеральної жирової тканини знижувалися на 21,6 та 12,1 \%. 
3. The prevalence of metabolic syndrome in various populations / G. Kolovou, K. Anagnostopoulou, K. Salpea, D. Mikhailidis // The American Journal of the Medical Sciences. - 2007. - No. 333. - P. 362-371.

4. The metabolic syndrome: prevalence and associated risk factor findings in the US population from the Third National Health and Nutrition Examination Survey, 1988-1994 / Y. W. Park, S. Zhu, L. Palaniappanet [et al.] // Archives of Internal Medicine. - 2003. No. 163. - P. 427-436.

5. Charles M. A.Metabolicsyndromeandhyperglyce mia: congruenceanddivergence/M. A. Charles, P. B. Landsman, S. M. Grundy // American Journal of Cardiology. 2006. - No. 98 (7). - P. 982-985.

6. Yin J. Insulin resistance determined by Homeostasis Model Assessment (HOMA) and associations with metabolic syndrome among Chinese children and teenagers [Published online] / J. Yin, M. Li, L. Xu // Diabetol. Metab. Syndr. - 2013. - 5. - P. 71. - Access mode: https://www.ncbi.nlm.nih.gov/pmc/articles/ PMC3833654/.

7. Cameron A. J. Themetabolicsyndrome: prevalen ceinworldwidepopulations / A. J. Cameron, J. E. Shaw, P. Z. Zimmet // Endocrinology and Metabolism Clinics of North America. - 2004. - 33 (2). - P. 351-375.

8. Imbalance in sex hormone levels exacerbates diabetic renal disease / Q. Xu, C. C. Wells, J. H. Garman [et al.] // Hypertension. - 2008. - 51 (4). - P. 1218-1224.

9. Insulin resistance of pregnancy involves estrogeninduced repression of muscle GLUT4 / R. P. Barros, A. Morani, A. Moriscot, U. F. Machado // Mol. Cell. Endocrinol. - 2008. - 25; 295 (1-2). - P. 24-31.

10. Aromatase, breast cancer and obesity: a complex interaction / S. E. Bulun, D. Chen, I. Moy [et al.] // Trends Endocrinol. Metab. - 2012. - № 23. - P. 83-89.

11. Obesity, body size, and risk of postmenopausal breast cancer: the Women's Health Initiative (United States) / L. M. Morimoto, E. White, Z. Chen [et al.] // Cancer Causes Control. - 2002. - 13. - P. 741-751.

12. Zumoff B. Relationship of obesity to blood estrogens / B. Zumoff // Cancer Res. - 1982. - 42 (8). P. 3289-3294.

13. Changes in testosterone levels and sex hormonebinding globulin levels in extremely obese men after bariatric surgery [Published online]/P. Boonchaya-anant, N. Laichuthai, P. Suwannasrisuk [et al.] // International Journal of Endocrinology. - 2016. - Access mode: http:// doi.org/10.1155/2016/1416503.

14. Correlation between sex hormone levels and obesity in the elderly male / J. Cao, T. M. Chen, W. J. Haoetal // Aging Male. - 2012. - 15 (2). - P. 85-89.

15. Effects of dietary carbohydrates on glucose and lipid metabolism in golden Syrian hamsters / S. E. KasimKarakas, H. Vriend, R. Almario [et al.] // J. Lab. Clin. Med. - 1996. - 128 (2). - P. 208-213.

16. Animal models of metabolic syndrome: a review / S. K. Wong, K.-Y. Chin, F. Hj. Suhaimi // Nutr. Metab. (Lond). - 2016. - 13. - P. 65.

17. Anroop B. N. A simple practice guide for dose conversion between animals and human / B. N. Anroop, J. Shery // J. Basic Clin. Pharm. - 2016 - 7 (2) . - P. 2731.

18. Доклинические исследования лекарственных средств : метод. рек. / под ред. А. В. Стесранова. - К. : Авиценна, 2002. - 528 с.

19. Popov D. Saturated-fat diet induces moderate diabetes and severe glomerulos clerosis in hamsters / D. Popov, M. Simionescu, P. R. Shepherd//Diabetologia. 2003. - 46. - P. 1408-1418.

20. Лапач С. Н. Статистические методы в медико-биологических исследованиях с использованием Excel / С. Н. Лапач, А. В. Чубенко, П. Н. Бабич. - К. : Морион, 2000. - 320 с.

21. Реброва О. Ю. Статистический анализ медицинских данных. Применение пакета прикладных программ STATISTICA/ О. Ю. Реброва. -3-е изд. -М. : МедиаСсрера, 2006. - 312 c.

22. Garg M. K. Studyofbeta-cellfunction (by HOMA model) inmetabolic syndrome / M. K. Garg, M. K. Dutta, N. Mahalle // Indian J. Endocrinol. Metab. - 2011. 15 (1). - P. 44-49.

23. Levy J. C. Correct homeostasis model assessment (HOMA) evaluation uses the computer program / J. C. Levy, D. R. Matthews, M. P. Hermans // Diabetes Care. - 1998. - 21 (12). - P . 2191-2192.

24. Laboratory animal medicine / Lynn C. Anderson, Glen Otto, Kathleen R. Pritchett-Corning, Mark T. Whary Elsevier, 2015. - 1746 p. - (Third Edition).

\section{REFERENCES}

1. Kaur, J. (2014). Comprehensive review on metabolic syndrome. Cardiology Research and Practice, Article ID 943162, Retrieved from: https://www.hindawi. com/journals/crp/2014/943162/.

2. Desroches, S., \& Lamarche, B. (2007). The evolving definitions and increasing prevalence of the metabolic syndrome. Applied Physiology, Nutrition and Metabolism, 32, 23-32.

3. Kolovou, G., Anagnostopoulou, K., Salpea K., \& Mikhailidis, D. (2007). The prevalence of metabolic syndrome in various populations. The American Journal of the Medical Sciences, 333, 362-371.
4. Park, Y.W., Zhu, S., \& Palaniappan, L. (2003). The metabolic syndrome: prevalence and associated risk factor findings in the US population from the Third National Health and Nutrition Examination Survey. Archives of Internal Medicine, 163, 427-436.

5. Charles, M.A., Landsman, P.B., \& Grundy, S.M. (2006). Metabolic syndrome and hyperglycemia: congruence and divergence. American Journal of Cardiology, 98 (7), 982-985.

6. Yin, J., Li, M., \& Xu, L. (2013). Insulin resistance determined by Homeostasis Model Assessment (HOMA) and associations with metabolic syndrome among 
Chinese children and teenagers. Diabetol. Metab. Syndr., 5, 71. Retrieved from: https://www.ncbi.nlm.nih. gov/pmc/articles/PMC3833654/.

7. Cameron, A.J., Shaw, J.E., \& Zimmet, P.Z. (2004). The metabolic syndrome: prevalence in worldwide populations. Endocrinology and Metabolism Clinics of North America, 33 (2), 351-375.

8. Xu, Q., Wells, C.C., \& Garman, J.H. (2008). Imbalance in sex hormone levels exacerbates diabetic renal disease. Hypertension, 51 (4), 1218-1224.

9. Barros, R.P., Morani, A., Moriscot, A., \& Machado, U.F. (2008). Insulin resistance of pregnancy involves estrogen-induced repression of muscle GLUT4. Mol. Cell. Endocrinol., 25, 295 (1-2), 24-31.

10. Bulun, S.E., Chen, D., \& Moy, I. (2012). Aromatase, breast cancer and obesity: a complex interaction. Trends Endocrinol. Metab., 23, 83-89.

11. Morimoto, L.M., White, E., \& Chen, Z. (2002). Obesity, body size, and risk of postmenopausal breast cancer: the Women's Health Initiative (United States). Cancer Causes Control, 13, 741-751.

12. Zumoff, B. (1982). Relationship of obesity to blood estrogens. Cancer Res., 42 (8), 3289-3294.

13. Boonchaya-anant, P., Laichuthai, N., \& Suwannasrisuk, P. (2016) Changes in testosterone levels and sex hormone-binding globulin levels in extremely obese men after bariatric surgery. International Journal of Endocrinology. Retrieved from: http://doi.org/10.1155/ 2016/1416503.

14. Cao, J., Chen, T.M., \& Hao, W.J. (2012). Correlation between sex hormone levels and obesity in the elderly male. Aging Male, 15 (2), 85-89.

15. Kasim-Karakas, S.E., Vriend, H., \& Almario, R. (1996). Effects of dietary carbohydrates on glucose and lipid metabolism in golden Syrian hamsters. J. Lab. Clin. Med., 128 (2), 208-213.

16. Wong, S.K., Chin, K.-Y., \& Hj, F. (2016). Suhaimi Animal models of metabolic syndrome: a review. Nutr. Metab. (Lond), 13, 65.

17. Anroop, B.N., \& Shery, J. (2016). A simple practice guide for dose conversion between animals and human. J. Basic Clin. Pharm., 7 (2), 27-31.

18. Stefanov, A.V. (Ed.). (2002). Preclinical research of drugs: method. Kyiv: Avicenna.

19. Popov, D., Simionescu, M., \& Shepherd, P.R. (2003). Saturated-fat diet induces moderate diabetes and severe glomerulo sclerosis in hamsters. Diabetologia, 46, 1408-1418.

20. Lapach, S.N., Chubenko, A.V., \& Babich, P.N. (2000). Statisticheskie metody v mediko-biologicheskikh issledovaniyakh s ispolzovaniyam Excel [Statistical methods in medical biological research using Excel]. Kyiv: Morion [in Russian].

21. Rebrova, O.Yu. (2006). Statistichekiy analiz meditsinskikh dannykh. Primeneniya paketa prikladnykh program STATISTICA [Statistic alanalysis of medical data. Application of the application package STATISTICA. 3rd ed]. Moscow: MediaSfera.

22. Garg, M.K., Dutta, M.K., \& Mahalle, N. (2011). Study of beta-cell function (by HOMA model) in metabolic syndrome. Indian J. Endocrinol. Metab., 15 (1), 44-49.

23. Levy, J.C., Matthews, D.R., \& Hermans, M.P. (1998). Correct homeostasis model assessment (HOMA) Evaluation Uses the Computer Program. Diabetes Care, 21 (12), 2191-2192.

24. Lynn, C. Anderson, Glen Otto, Kathleen R. Pritchett-Corning, \& Mark, T. Whary (2015). Laboratory animal medicine. Elsevier.

\section{ВЛИЯНИЕ ИНГИБИТОРОВ АРОМАТАЗЫ ТРЕТЬЕГО ПОКОЛЕНИЯ НА ОТДЕЛЬНЫЕ КОМПОНЕНТЫ ТЕЧЕНИЯ ЭКСПЕРИМЕНТАЛЬНОГО МЕТАБОЛИЧЕСКОГО СИНДРОМА}

\section{Резюме}

Вступление. На сегодняшний день среди больных с метаболическим синдромом около 86 \% пациентов имеют серьезные нарушения толерантности к глюкозе и около 60 \% пациентов страдают от висцерального ожирения. При этом во многих мировых исследованиях показано, что эти патогенетические проявления метаболического синдрома у исследуемых пациентов имели значительную корреляцию с дисбалансом половых гормонов.

Цель исследования - изучить влияние ингибиторов ароматазы третьего поколения на показатели инсулинорезистентности и висцерального ожирения у хомячков с экспериментальным метаболическим синдромом.

Методы исследования. Уровень инсулина в сыворотке крови хомячков определяли иммуноферментным методом, а уровень глюкозы - электрохимическим. Для оценки висцерального ожирения рассчитывали массовые коэфффициенты анатомических фррагментов жировой ткани. Полученные результаты были обработаны с применением U-критерия Манна-Уитни и метода 4PI. 
Результаты и обсуждение. Все изучаемые препараты в той или иной степени влияли на исследуемые патогенетические компоненты течения экспериментального метаболического синдрома. Наибольшую эфрфективность по уменьшению показателя инсулинорезистентности продемонстрировал препарат “Экземестан”, а при уменьшении степени висцерального ожирения - “Летрозол".

Вывод. Ингибиторы ароматазы могут стать перспективными препаратами для воздействия на патогенетические компоненты метаболического синдрома, в частности на инсулинорезистентность и висцеральное ожирение.

КЛЮЧЕВЫЕ СЛОВА: ароматаза; ингибиторы; метаболический синдром; висцеральный жир; инсулинорезистентность; летрозол; анастрозол; экземестан.

A. L. Zagayko, D. V. Lytkin, A. V. Maloshtan NATIONAL UNIVERSITY OF PHARMACY, KHARKIV

\title{
THE EFFECT OF THIRD GENERATION AROMATASE INHIBITORS ON THE SEVERAL COMPONENTS OF EXPERIMENTAL METABOLIC SYNDROME
}

\begin{abstract}
Summary
Introduction. Nowadays, about $86 \%$ among patients with metabolic syndrome have serious disorder of glucose tolerance and about $60 \%$ of them suffer from visceral obesity. Moreover in many worldwide studies it was shown that these pathogenetic manifestations of the metabolic syndrome had a significant correlation with the imbalance of sex hormones.

The aim of the study - to learn the effect of third-generation aromatase inhibitors on the parameters of insulin resistance and visceral obesity in hamsters with the experimental metabolic syndrome.

Research Methods. The insulin level in the hamster's blood serum was measured by the enzyme immunoassay method, and the glucose level by the electrochemical method. The mass coefficients of anatomical fragments of adipose tissue were calculated to estimate visceral obesity. The results were processed by using the MannWhitney U-test and the 4PI method.

Results and Discussion. All studied drugs, in varying degrees, influenced on the pathogenetic components of the experimental metabolic syndrome. Exemestane was demonstrated the greatest effectiveness in reducing parameter of the insulin resistance by, butletrozole - in decreasing of visceral obesity ratio.

Conclusion. Romatase inhibitors can become promising drugs for correcting the pathogenetic components of the metabolic syndrome, in particular insulin resistance and visceral obesity.
\end{abstract}

KEY WORDS: aromatase; inhibitors; metabolic syndrome; visceral fat; insulinresistance; letrozole; anastrozole; exemestane.

Отримано 25.10.17

Адреса для листування: Д. В. Литкін, Національний фармацевтичний університет, вул. Пушкінська, 53, Харків, 61002, Україна, email:d.v.lytkin@gmail.com. 